\title{
DETERMINATION OF OPTIMAL LOCATION OF SOIL MOISTURE SENSING DEVICES FOR TRICKLE IRRIGATION SYSTEMS
}

\author{
M.K.Elnemr ${ }^{1}$, A.M.El-Sheikha ${ }^{2}$, and E.A.Elsadek ${ }^{3}$
}

\begin{abstract}
Moisture sensing devices are considered the main element to reach better irrigation management especially for irrigation systems that are based on automatic control. Moisture devices location accuracy may affect the accuracy of their sent data which will lead to a poor performance under various operating conditions and consequently, affect irrigation efficiency that affects dependency on water productivity and thus, water use energy efficiency. For this purpose, a lab experiment was carried out using a fiberglass box (100 x $100 \times 20 \mathrm{~cm})$ and digital moisture meter (SKZDM300L), 2 digits accuracy to determine the optimal position of a calibrated moisture sensing device. The experiment was carried out on two soil types (sandy, and clay) under three flow rates (4.2, 5.6, and 6.2 l/h) for each soil type. Soil moisture content (SMC) average and total moisture content average were calculated for both soil types throughout four investigation periods $(6,12,24$, and 48 h) respectively, after applying the water for an hour. Standard deviation (SD) was estimated for each quarter of the total investigation depth to determine the amount of variation or dispersion of the obtained average (mean) moisture content values. For sandy soil, $(15 \mathrm{~cm})$ vertically (under the emission point directly) is the optimal position recommended putting a calibrated moisture sensing device use in irrigation scheduling under the lowest flow rate $(4.2 \mathrm{l} / \mathrm{h})$ whereas, $(15,15 \mathrm{~cm})$ horizontally and vertically respectively, (from the emission point) is recommended for clay soil under flow rate $(5.6 \mathrm{l} / \mathrm{h})$ to obtain highly irrigation efficiency and thus, highly water productivity and water use energy efficiency.
\end{abstract}

Keywords: Moisture distribution, soil moisture content, moisture sensing devices, operating pressures, discharge rate, optimal sensor location.

1,2 Associate professor, Department of Agricultural Engineering, Faculty of Agriculture. Damietta University. Egypt

3. Demonstrator, Department of Agricultural Engineering, Faculty of Agriculture. Damietta University. Egypt 


\section{INTRODUCTION}

oil moisture content (SMC) is a major determinant of plant growth and crop productivity. SMC has a major role in ecological and hydrological processes at different scales, including root water absorption, photosynthesis, nutrient transport, evapotranspiration, infiltration, runoff, and soil erosion (Chaney et al., 2015). Therefore, Investigation of the soil moisture dynamics of agricultural lands is vital not only to improve agricultural water use efficiency, but also to understand the impact of agricultural cultivation and irrigation on the water cycle (Ren et al., 2016).Consequently, it must be a considerable parameter in environmental, agricultural, hydrological, and geotechnical studies and projects (Brocca et al.,2014).Soil moisture content (SMC) shows high spatiotemporal variability, its spatial pattern is characterized by temporal stability, defined as the temporal persistence of spatial patterns of soil water content over time(Joshi et al., 2011).The temporal stability concept can be used to determine locations that represent the mean SMC of an area, to up- or downscale SMC measurements, and to provide missing data in hydrological analyses (Penna et al., 2013). It can also be used to determine the mean SMC of an area using a small number of monitoring points, which saves time and reduces the labor required compared with traditional monitoring methods (Jia et al., 2013).Micro irrigation systems have greater potential for accurate irrigation delivery than other irrigation systems and also easily to control and are commonly automated on a time, soil moisture, or time-temperature basis (Evett et al., 2006).Automation of these irrigation systems plays an important role in the provision of water efficiency in agricultural farming systems irrigated because it can provide the required amount of water in a timely manner according to the needs of the plant and the circumstances of the actual water throughout the seasons of the year (Boutraa et.,2011).According to Irrigation Association., 2007 a variety of technologies are designed to minimize excessive irrigation by measuring or estimating soil moisture content these technologies include soil moisture sensor (SMS) controllers, evapotranspiration (ET) based controllers and rain sensors. Many researchers have investigated the automation of irrigation systems and the use of soil moisture sensing 
devices such as tensiometers, gypsum blocks, granular matrix sensors (GMS), and electromagnetic (EM) sensors. Several studies investigated the use of EM sensors in novel automated irrigation management applications (Miralles-Crespo and Van Iersel., 2011). In these studies, significant water savings in comparison with traditional irrigation scheduling approaches, as high as $60 \%$, were reported without a negative effect on crop yield. Blonquist et al., 2006 installed a soil moisture sensor(time domain transmission) for the registration of volumetric water content in the soil, compared with an irrigation threshold, and link this to a solenoid valve on the irrigation line supplying water to the irrigation system. This system applied 53\% less water than under the traditional method. Ooi et al., 2010 used automation to irrigate an apple orchard, The system developed allowed fully automated on-farm irrigation based on real-time feedback control increased economic water use efficiency and water use efficiency by $73 \%$ compared with the manual irrigation system. Large variations in water content and matric potential may exceed the range of operation for certain sensors (e.g., tensiometers).Also, Soil moisture sensors positioning and accuracy may affect the performance and irrigation efficiency of soil moisture based irrigation scheduling systems under various conditions (soil types, potential evapotranspiration rates, discharge rates, irrigation depths, drip line spacing).(Soulis et al., 2015).Also, as position of sensors plays a significant role in irrigation scheduling as poor sensor positioning that is not representative of the soil moisture conditions in the root zone can result either in crop water stress, or in over-irrigation that negates the water saving capabilities of soil moisture scheduling (Wang et al., 2012). Thus, in agriculture, knowledge of soil moisture allows proper irrigation management and forecasting of crop yields (Grabow et al., 2013).Soil moisture wetting patterns can be obtained either experimentally, which are case-specific, or by simulation using suitable mathematical models. As a result, several studies were conducted to understand the extent and patterns of spatial and temporal variations in water content and matric potential within drip irrigated fields (Or., 1996).

Usually, many of these irrigation studies focus on the top 1-2 m or even shallower depths, as the root zone or depth of interest, with a hypothetical 
bottom boundary condition (Karandish and Simunek., 2016). However, few studies have investigated the distribution of SMC temporal stability characteristics at a fine scale (e.g., every $20 \mathrm{~cm}$ or less) (Gao et al., 2015).In this context, the main purpose of this study is to investigate the influence of soil moisture sensor position on the performance of soil moisture based irrigation scheduling systems under different conditions of soil types, flow rates and investigation periods $(6,12,24$, and $48 \mathrm{~h})$ to determine the optimal location of a moisture sensing device under conditions of soil moisture based irrigation scheduling systems to maximize water productivity and thus, water use energy efficiency.

\section{MATERIALS AND METHODS}

\subsection{Physical description of the experiment.}

A lab experiment was carried out using a transparent fiber glass box (100 x $100 \times 20 \mathrm{~cm}$ ) as shown in Fig.1 to simulate a soil profile to the root zone area. The box was made of fiberglass to facilitate the observation of water movement in the soil profile after water application. A grid of holes was drilled in one side of the box on equal spaces $(5 \mathrm{~cm}$ in both horizontal and vertical directions) from the emission point to investigate soil moisture content distribution throughout the soil. Long path outline emitter was fixed at the emission point $(0,0)$ coordinates. One terminal of the lateral (16 mm inner diameter) was connected to the water supply and the other terminal was closed by an end cap. The investigation was carried out after applying the water for an hour from the emission source. The total investigation area was $80 \mathrm{~cm}$ width $(40 \mathrm{~cm}$ horizontally on both side of the emission point) and $60 \mathrm{~cm}$ depth. Electric conductivity (EC) of the applied water was measured and an amount of water was applied to the box before the experiments in order to leach the salts in the soil to avoid the expected effect of their non-uniform distribution in the proposed sensing device's readings accuracy. The bottom of the box had a drain hole to discharge the leaching water. This water EC was measured gradually till reaching a reading near to the $\mathrm{EC}$ of applied water. 


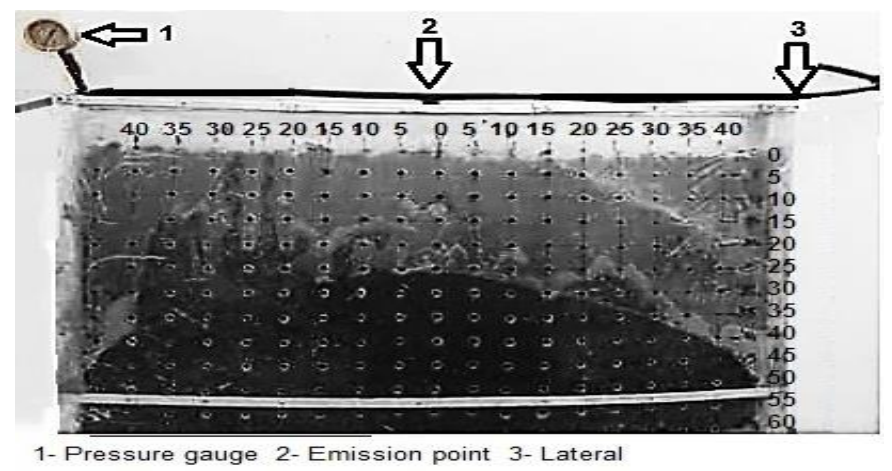

Fig.1.Root zone simulation box.

\subsection{Variables.}

\subsubsection{Emitter flow rate.}

Three flow rates $(4.2,5.6$, and $6.21 / \mathrm{h})$ were used during the study to change the behavior of water movement which will be investigated to consider the expected variation in the distribution of soil moisture content in the root zone. This is expected to clarify whether there will be a change in the selected position of the sensor regarding the variation of water movement and wetting-front advance or not. The change in emitter flow rate was achieved by using three operating pressure heads $(5,8$, and $10 \mathrm{~m}$ of water) that are suitable for trickle irrigation network operation. Operating pressure head was measured by using pressure gauge $1 \mathrm{~m}$ accuracy which was monitored continuously during operation to avoid any change that may happen in the pressure which was controlled by a valve at the water outlet source.

\subsubsection{Soil texture.}

Clay and sandy soil types were studied to determine the optimal position of the moisture sensing device for each soil type. The used volume of each soil type which was put in the box was transferred from outside field. The used soils were sifted before entering the box and compacted by hand to avoid the existence of gravels or air cavities that may affect the measurements. The soil leaching process helped in soil compaction and the soil was allowed to dry before the tests.

\subsubsection{Investigation periods.}

The investigation was carried out for each soil type for four investigation periods $(6,12,24,48 \mathrm{hs})$ after applying the water for an hour from the emission source. 


\subsection{Moisture investigation.}

A digital moisture meter (SKZ-DM300L), 2digits accuracy was used to investigate soil moisture distribution throughout the soil profile. The probe of the device was assumed to act any proposed sensing device. The device was calibrated before investigation to ensure its accuracy. The gravitational method was used to calculate the moisture content of the two soil types (sandy and clay) by putting the wet sample in a pot and recorded the weight of the sample (wet weight) and then, samples were dried at $105{ }^{\circ} \mathrm{C}$ for $24 \mathrm{~h}$. Soil moisture content was measured by the device before the drying process. Six different weight samples for each type of soil were used in the calibration. The dry weight was recorded to calculate the per cent of moisture content referring to the formula used by (Gardner et al., 2001).

The obtained results were fed to software (curve expert version 1.3) to obtain the calibration formula which resulted as follows:

$$
M . C_{a c t}=-1.4618033\left(M . C_{R}\right)^{2}+16.111724\left(M . C_{R}\right)-1.021357
$$

Where: $\mathrm{MC}_{\text {act }}$ : Actual soil moisture content, \%,

$\mathrm{MC}_{\mathrm{R}}$ :Moisture content read by the device.

\subsection{Soil moisture content variation.}

The standard deviation (SD) is a measure that is used to quantify the amount of variation or dispersion of a set of data values (Bland and Altman., 1996).As a result, SD were estimated for each quarter of the total investigation depth to determine the amount of variation or dispersion of the obtained average (mean) moisture content values by using the following equation (Middleton., 2006).

$$
\mathbf{S D}=\sqrt{\frac{\sum_{\mathbf{i}=\mathbf{1}}^{\mathrm{N}}\left(\mathbf{x}-\mathbf{x}^{-}\right)^{2}}{\mathbf{N}-\mathbf{1}}}
$$

Where: $\mathrm{x}$ : Each of investigated moisture content point value.

$\mathrm{x}^{-}$: Mean value of soil moisture content in the investigated points.

$\mathrm{N}$ : Number of investigated points. 


\section{RESULTS AND DISCUSSION}

\subsection{Moisture content variation.}

\subsubsection{Soil texture effect.}

The obtained results are listed in (Table 1,and 2),by comparing two soil types (sandy, and clay) under the study, the obtained results indicate large variation in moisture content average throughout the investigation periods for the same flow rate values, for example, after $(6 \mathrm{~h})$ the values were $(1.53,1.88,2.86$, and $6.94 \%)$ respectively, for sandy soil under flow rate $(4.2 \mathrm{l} / \mathrm{h})$ as shown in (Table 1), while the values were $(20.04,17.02,9.25$, and $4.85 \%$ ) respectively, for clay for the same investigation period under the same flow rate as shown in (Table 2). For sandy soil, the observed increase in the values of moisture content average in the latest quarter of the root zone area $(45-60 \mathrm{~cm})$ during the investigation periods $(6,12,24$, and $48 \mathrm{~h}$ ) respectively, under three flow rates $(4.2,5.6$, and $6.2 \mathrm{l} / \mathrm{h}$ ) as shown in (Table 1) maybe because of the accumulation of the water in the latest quarter of the fiberglass box due to the decrease in water drainage rate through the drainage holes because of the fast downward movement in vertical direction where macro-pores are dominant in sandy soil. On the other hand, for sandy soil, the obtained results illustrated that the increase in flow rate from $(4.2 \mathrm{l} / \mathrm{h})$ up to $(6.2 \mathrm{l} / \mathrm{h})$ led to increase in the total average of moisture content from $(3.30,3.30,2.86$, and $2.53 \%)$ to $(4.58,4.53,4.46$, and $4.45 \%)$ by an estimated increase of $(27.94,27.15,35.87$, and $43.15 \%)$ for the investigation periods $(6,12,24$, and $48 \mathrm{~h}$ ) respectively, as shown in (Table 3). In comparison, for clay soil, there was also an increase in the total average of moisture content from $(12.79,12.18,10.98$, and $10.96 \%)$ to $(19.30,19.18,18.91$, and 17.69 $\%)$ by an estimated increase of $(33.73,36.49,41.93$ and $38.04 \%)$ respectively, under the same flow rate values and for the same investigation periods as shown in (Table 4). These obtained results of moisture content and total average of moisture content were compatible with (Siyal and Skaggs., 2009) who illustrated that the water content in the wetted zone was the largest in the clay loam, followed by the loam and sandy loam. (McNeal et al., 1995) illustrated that sandy soils generally have higher internal drainage with a lower water holding capacity than finer-textured soils. Also, This difference in moisture content average values actually due to the fact that, clay soil is different 
from sandy soil in texture, structure, water holding capacity, nutrient status, soil strength and even soil temperature (Coelho and Or., 1999) and the difference between soil texture (coarse or fine) is considered to be the main factor that affects soil water movement (Jury and Horton., 2004). These obtained values of total average moisture content were used to determine the horizontal and vertical dimensions which meet the recommended location to put a moisture sensing device in the sandy and the clay soil as shown in (Table $\mathbf{3}$, and $\mathbf{4}$ ).

\subsubsection{Flow rate effect.}

The obtained results shown in (Table 1, and 2) showed variation in the average of moisture content values along the wetted- front for each quarter of the root zone $(0-60 \mathrm{~cm})$.For the two soil types (sandy, and clay) , there was a positive correlation between the average of moisture content values and the increase in flow rate up to $(6.2 \mathrm{l} / \mathrm{h})$ and this variation consequently led to different values of standard deviation, for sandy soil, the obtained results shown in (Table 1) indicate that the lowest flow rate $(4.2 \mathrm{l} / \mathrm{h})$ caused in the lowest standard deviation values $(0.64,0.62,0.65$, and 0.77$)$ respectively, along the investigation depth $(0-15$ $\mathrm{cm})$ throughout the investigation periods $(6,12,24$, and $48 \mathrm{~h})$ respectively, followed by flow rates $(5.6$,and $4.21 / \mathrm{h})$. In contrast, for clay soil, the obtained results as shown in (Table 2) illustrate that, for the same depth, the flow rate $(5.6 \mathrm{l} / \mathrm{h})$ caused in the lowest standard deviation values $(11.55,11.03,11.50$, and 12.72) respectively, for the same investigation periods followed by flow rates $(6.2$, and $4.2 \mathrm{l} / \mathrm{h})$. Whereas, the lowest standard deviation values refers to a convergence in the moisture content values along the investigation depth $(0: 15 \mathrm{~cm})$ as the low standard deviation values indicate that the values of moisture content for the investigation points tend to be close to the mean of the set, while the high standard deviation values which opposite $(15: 60 \mathrm{~cm})$ depth indicate that the values of moisture content for the investigation points are spread out over a wider range of values. The obtained results provided clear evidence that the first quarter of the root zone area is the most important quarter in this was actually fully compatible with (USDA., 1997) which indicated that the most effective root zone depth where most of the field crops extract $40 \%$ of the water uptake takes place from the first quarter of the total rooting depth. 
Table 1: Average (MC) \%, and the standard deviation values for sandy soil.

\begin{tabular}{|c|c|c|c|c|c|c|c|}
\hline \multirow{2}{*}{$\begin{array}{l}\text { Investigation } \\
\text { interval ,h }\end{array}$} & \multirow{2}{*}{$\begin{array}{c}\text { Depth, } \\
\text { cm }\end{array}$} & \multicolumn{3}{|c|}{ Average (MC), \% } & \multicolumn{3}{|c|}{ Standard deviation. } \\
\hline & & $4.2 \mathrm{l} / \mathrm{h}$ & $5.6 \mathrm{l} / \mathrm{h}$ & $6.2 \mathrm{l} / \mathrm{h}$ & $4.2 \mathrm{l} / \mathrm{h}$ & $5.6 \mathrm{l} / \mathrm{h}$ & $6.2 \mathrm{l} / \mathrm{h}$ \\
\hline \multirow{4}{*}{6} & $0-15$ & 1.53 & 2.05 & 2.83 & 0.64 & 0.77 & 0.78 \\
\hline & $15-30$ & 1.88 & 2.39 & 2.99 & 1.29 & 1.08 & 1.22 \\
\hline & $30-45$ & 2.86 & 3.13 & 3.90 & 2.48 & 1.56 & 2.27 \\
\hline & $45-60$ & 6.94 & 8.68 & 8.59 & 5.28 & 3.80 & 4.24 \\
\hline \multirow{4}{*}{12} & $0-15$ & 1.53 & 2.44 & 2.61 & 0.62 & 0.77 & 0.72 \\
\hline & $15-30$ & 1.88 & 2.61 & 2.74 & 1.02 & 1.08 & 0.76 \\
\hline & $30-45$ & 2.86 & 3.35 & 3.86 & 2.13 & 1.56 & 2.35 \\
\hline & $45-60$ & 6.94 & 7.96 & 8.89 & 4.12 & 3.80 & 4.95 \\
\hline \multirow{4}{*}{24} & $0-15$ & 1.45 & 2.48 & 2.48 & 0.65 & 0.79 & 0.65 \\
\hline & $15-30$ & 1.62 & 2.48 & 2.82 & 0.65 & 1.05 & 0.86 \\
\hline & $30-45$ & 2.08 & 3.07 & 3.73 & 1.36 & 1.66 & 2.08 \\
\hline & $45-60$ & 6.32 & 7.43 & 8.74 & 4.30 & 4.03 & 4.88 \\
\hline \multirow{4}{*}{48} & $0-15$ & 1.36 & 2.53 & 2.83 & 0.77 & 0.79 & 0.78 \\
\hline & $15-30$ & 1.40 & 2.57 & 2.83 & 0.70 & 1.02 & 0.78 \\
\hline & $30-45$ & 1.87 & 2.99 & 3.89 & 1.22 & 1.63 & 2.43 \\
\hline & $45-60$ & 5.51 & 7.25 & 8.29 & 3.99 & 3.77 & 4.60 \\
\hline
\end{tabular}

Table 2: Average (MC) \%, and the standard deviation values for clay soil.

\begin{tabular}{|c|c|c|c|c|c|c|c|}
\hline \multirow{2}{*}{$\begin{array}{c}\text { Investigation } \\
\text { interval }, \mathrm{h}\end{array}$} & \multirow{2}{*}{$\begin{array}{c}\text { Depth, } \\
\text { cm }\end{array}$} & \multicolumn{3}{|c|}{ Average (MC), \% } & \multicolumn{3}{|c|}{ Standard deviation. } \\
\hline & & $4.2 \mathrm{l} / \mathrm{h}$ & $5.6 \mathrm{l} / \mathrm{h}$ & $6.2 \mathrm{l} / \mathrm{h}$ & $4.2 \mathrm{l} / \mathrm{h}$ & $5.6 \mathrm{l} / \mathrm{h}$ & $6.21 / h$ \\
\hline \multirow{4}{*}{6} & $0-15$ & 20.04 & 17.87 & 16.69 & 15.59 & 11.55 & 12.35 \\
\hline & $15-30$ & 17.02 & 18.47 & 19.54 & 15.71 & 13.68 & 14.46 \\
\hline & 30-45 & 9.25 & 18.48 & 20.13 & 9.18 & 14.63 & 14.96 \\
\hline & $45-60$ & 4.83 & $\mathbf{1 7 . 3 3}$ & 20.86 & 1.90 & 14.13 & 15.60 \\
\hline \multirow{4}{*}{12} & $0-15$ & 16.17 & 17.96 & 17.41 & 12.09 & 11.03 & 12.45 \\
\hline & $15-30$ & 17.03 & 18.77 & 19.29 & 13.50 & 13.37 & 14.03 \\
\hline & $30-45$ & 10.46 & 17.71 & 19.90 & 9.84 & 14.53 & 14.77 \\
\hline & $45-60$ & 5.05 & 16.27 & 20.12 & 1.64 & 13.94 & 14.96 \\
\hline \multirow{4}{*}{24} & $0-15$ & 16.02 & 16.34 & 16.82 & 12.70 & 11.50 & 12.68 \\
\hline & 15-30 & 15.44 & 17.80 & 19.53 & 12.69 & 12.95 & 14.43 \\
\hline & $30-45$ & 8.27 & 16.97 & 19.37 & 8.93 & 13.50 & 14.34 \\
\hline & $45-60$ & 4.18 & 15.62 & 19.93 & 1.55 & 12.54 & 14.76 \\
\hline \multirow{4}{*}{48} & $0-15$ & 15.62 & 15.19 & 16.69 & 12.64 & 12.72 & 12.30 \\
\hline & $15-30$ & 14.55 & 17.32 & 18.35 & 12.84 & 14.40 & 13.38 \\
\hline & $30-45$ & 9.06 & 17.45 & 17.78 & 7.94 & 14.54 & 12.97 \\
\hline & $45-60$ & 4.59 & 16.86 & 17.96 & 1.01 & 13.87 & 13.05 \\
\hline
\end{tabular}




\subsection{Investigation period and wetting-front advance.}

By investigating the points which represented the total moisture content average, the results shown in (Table $\mathbf{3}$, and $\mathbf{4}$ ) have been reached which represent its recommended location from the discharge source. For two soil types, the obtained results illustrate that by increasing the flow rate up to $(6.2 \mathrm{l} / \mathrm{h})$, the total moisture content average movement increased along the wetting-front for the vertical and horizontal directions throughout the investigation period $(6,12,24,48 \mathrm{~h})$ respectively, but the movement in the vertical direction was clearly high for sandy soil which reached the maximum depth value $(60 \mathrm{~cm})$ vertically compared with clay soil which reached $(35 \mathrm{~cm})$ vertically under the same flow rate $(6.2 \mathrm{l} / \mathrm{h})$ at the end of the investigation period $(48 \mathrm{~h})$, while the results showed decreasing in the horizontal movement of the total moisture content average compared with the movement in the vertical direction which ranged from $(0: 15 \mathrm{~cm})$ horizontally for both two soil types (sandy, clay) throughout the investigation period. The obtained results stressed the concept that using the high flow rate (e.g., $6.2 \mathrm{l} / \mathrm{h}$ ) in a single irrigation event maybe result in moving the irrigation water out the effective root zone of the plants. Whereas, using the high flow rate which leads to increase in vertical movement than horizontal movement especially for sandy soil where macro-pores are dominant and allow for fast downward movement and this maybe lead to increase deep percolation which leads to exposing the irrigation water to move beyond the effective root zone especially at the initial stage of growth. Also, the results provided clear evidence the total moisture content average is spatiotemporal variable and these results were in agreement with (Liu and Shao., 2014) who illustrated that soil moisture content (SMC) shows high spatiotemporal variability. Also, The results are compatible with (Siyal and Skaggs., 2009) who found that vertical wetting distances in soil treated with a porous clay pipe under positive pressure irrigation were in the order of sandy loam, loam and clay loam respectively, and the horizontal wetting distances were in the order of loam, sandy loam and clay loam respectively. Furthermore, the water content in the wetted zone was the largest in the clay loam, followed by the loam and sandy loam. Also, there was an agreement with 
(Jiu-Sheng, et al., 2007) where in uniform coarse-textured soils, like sandy soils, a greater wetted depth (area) was obtained by the use of emitters having smaller application rate. Also, (Levin et al., 1979) who used emitters with different discharge rates, found that increasing discharge rate up to $(8 \mathrm{l} / \mathrm{h})$ resulted in an increase of wetting area in the vertical direction and a decrease in the horizontal direction and thus, emitters of high discharge rate of $(8 \mathrm{l} / \mathrm{h})$ caused water runoff on fine textured soils, and emitters of discharge of $(4 \mathrm{l} / \mathrm{h})$ are recommended to use in this soil and they reported that emitters of $(4 \mathrm{l} / \mathrm{h})$ could be used in sandy soils .Also, the results obtained by (Ragheb., 1997) showed that daily irrigation at a rate of $(4 \mathrm{l} / \mathrm{h})$ or lower resulted in gradual and moderate variation of water distribution in the root zone within the irrigation period.

Table 3: Total average (MC), \% and recommended distance from water source, cm for sandy soil.

\begin{tabular}{|c|c|c|c|c|c|c|c|c|c|}
\hline \multirow{4}{*}{$\begin{array}{c}\text { Invest. } \\
\text { period } \\
, \mathbf{h}\end{array}$} & \multicolumn{3}{|c|}{$\begin{array}{c}\text { Total average } \\
\text { (MC), \% }\end{array}$} & \multicolumn{6}{|c|}{ Distance from water source ,cm } \\
\hline & \multirow{3}{*}{$\begin{array}{l}4.2 \\
1 / h\end{array}$} & \multirow{3}{*}{$\begin{array}{l}5.6 \\
1 / h\end{array}$} & \multirow{3}{*}{$\begin{array}{l}6.2 \\
1 / h\end{array}$} & 4.2 & & 5.6 & & 6.2 & \\
\hline & & & & \multicolumn{6}{|c|}{ Direction } \\
\hline & & & & Horiz. & Vert. & Horiz. & Vert. & Horiz. & Vert. \\
\hline 6 & 3.30 & 4.09 & 4.58 & $\mathbf{0}$ & 15 & 10 & 45 & 15 & 40 \\
\hline 12 & 3.30 & 4.06 & 4.53 & $\mathbf{0}$ & 20 & 15 & 45 & 15 & 45 \\
\hline 24 & 2.86 & 3.86 & 4.46 & $\mathbf{0}$ & 25 & 15 & 45 & 10 & 55 \\
\hline 48 & 2.53 & 3.83 & 4.45 & $\mathbf{0}$ & 25 & 10 & 50 & 10 & 60 \\
\hline
\end{tabular}

Table 4: Total average (MC), \% and recommended distance from water source, $\mathrm{cm}$ for clay soil.

\begin{tabular}{|c|c|c|c|c|c|c|c|c|c|}
\hline \multirow{4}{*}{$\begin{array}{c}\text { Invest. } \\
\text { period } \\
\text {,h }\end{array}$} & \multicolumn{3}{|c|}{ Average (MC), \% } & \multicolumn{6}{|c|}{ Distance from water source ,cm } \\
\hline & \multirow{3}{*}{$\begin{array}{l}4.2 \\
1 / h\end{array}$} & \multirow{3}{*}{$\begin{array}{l}5.6 \\
1 / h\end{array}$} & \multirow{3}{*}{$\begin{array}{l}6.2 \\
1 / h\end{array}$} & 4.2 & & 5.6 & & & \\
\hline & & & & \multicolumn{6}{|c|}{ Direction } \\
\hline & & & & Horiz. & Vert. & Horiz. & Vert. & Horiz. & Vert. \\
\hline 6 & 12.79 & 18.04 & 19.30 & 15 & $\mathbf{0}$ & $\mathbf{0}$ & 10 & $\mathbf{0}$ & 10 \\
\hline 12 & 12.18 & 17.68 & 19.18 & 15 & $\mathbf{0}$ & 5 & 15 & $\mathbf{0}$ & 25 \\
\hline 24 & 10.98 & 17.68 & 18.91 & 15 & $\mathbf{0}$ & 10 & 15 & $\mathbf{0}$ & 35 \\
\hline 48 & 10.96 & 16.68 & 17.69 & 15 & $\mathbf{0}$ & 15 & 15 & $\mathbf{0}$ & 35 \\
\hline
\end{tabular}




\section{CONCLUSION}

The obtained results indicated large variation in moisture content average at different depths $(0: 60 \mathrm{~cm})$ throughout the investigation periods for the same flow rate values, for example, after $(6 \mathrm{~h})$ the values were $(1.53$, $1.88,2.86$, and $6.94 \%)$ respectively, for the sandy soil under flow rate $(4.2 \mathrm{l} / \mathrm{h})$, while the values were $(20.04,17.02,9.25$, and $4.85 \%)$ respectively, for the clay for the same investigation interval under the same flow rate. On the other hand, for the sandy soil, the obtained results illustrated that the increase in flow rate from $(4.2 \mathrm{l} / \mathrm{h})$ up to $(6.2 \mathrm{l} / \mathrm{h})$ led to increase in the total average of moisture content from $(3.30,3.30,2.86$, and $2.53 \%)$ to $(4.58,4.53,4.46$, and $4.45 \%)$ by an estimated increase of $(27.94,27.15,35.87$, and $43.15 \%)$ for the investigation periods $(6,12,24$, and $48 \mathrm{~h}$ ) respectively. In comparison, for clay soil, there was also an increase in the total average of moisture content from $(12.79,12.18$, 10.98 , and $10.96 \%)$ to $(19.30,19.18,18.91$, and $17.69 \%)$ by an estimated increase of $(33.73,36.49,41.93$ and $38.04 \%)$ respectively, under the same flow rate values and for the same investigation periods. Also, the obtained results illustrated also that, for both soil types, by increasing the flow rate up to $(6.2 \mathrm{l} / \mathrm{h})$ there was a clear variation in moisture content average and wetting-front advance (horizontal and vertical) throughout the investigation period the wetting-front advance.

For the sandy soil, the lowest flow rate $(4.2 \mathrm{l} / \mathrm{h})$ caused in the lowest standard deviation values $(0.64,0.62,0.65$, and 0.77$)$ respectively, along the investigation depth $(0: 15 \mathrm{~cm})$ which refers to a convergence in the moisture content values along the investigation depth $(0: 15 \mathrm{~cm})$ throughout the investigation periods $(6,12,24$, and $48 \mathrm{~h})$ respectively, followed by flow rates $(5.6$, and $4.2 \mathrm{l} / \mathrm{h}$ ). In contrast, for clay soil, the flow rate $(5.61 / \mathrm{h})$ caused in the lowest standard deviation values $(11.55$, $11.03,11.50$, and 12.72) respectively, for the same depth and the same investigation periods followed by flow rates (6.2, and $4.2 \mathrm{l} / \mathrm{h}$ ).

It is recommended to locate a calibrated moisture sensing device in dimensions $(15 \mathrm{~cm})$ vertically (under the emission point) under flow rate 
(4.2 $\mathrm{l} / \mathrm{h})$ for the sandy soil and $(15$, and $15 \mathrm{~cm})$ in horizontal and vertical directions (from the emission point) respectively, under flow rate $(5.6 \mathrm{l} / \mathrm{h}$ ) in the clay soil to avoid water irrigation losses and maximize water productivity and thus, water use energy efficiency.

\section{REFERENCES}

Bland, J. M., and Altman, D. G. (1996).Statistics notes: measurement error. Bmj, 313(7059), 744.

BlonquistJr, J. M., Jones, S. B., and Robinson, D. A. (2006).Precise irrigation scheduling for turfgrass using a subsurface electromagnetic soil moisture sensor. Agricultural water management, 84(1-2), 153-165.

Boutraa, T., Akhkha, A., Alshuaibi, A., and Atta, R. (2011).Evaluation of the effectiveness of an automated irrigation system using wheat crops. Agriculture and Biology Journal of North America, 2(1), 8088 .

Brocca, L., Camici, S., Melone, F., Moramarco, T., MartínezFernández, J., Didon-Lescot, J. F., andMorbidelli, R. (2014).Improving the representation of soil moisture by using a semi-analytical infiltration model. Hydrological Processes, 28(4), 2103-2115.

Chaney, N. W., Roundy, J. K., Herrera-Estrada, J. E., and Wood, E. F. (2015). High-resolution modeling of the spatial heterogeneity of soil moisture: Applications in network design. Water Resources Research, 51(1), 619-638.

Coelho, E. F., and Or, D. (1999). Root distribution and water uptake patterns of corn under surface and subsurface drip irrigation. Plant and Soil, 206(2), 123-136.

Evett, S. R., Peters, R. T., and Howell, T. A. (2006, June). Controlling water use efficiency with irrigation automation: Cases from drip 
and center pivot irrigation of corn and soybean. In Proc. 28th Annual Southern Conservation Systems Conf (pp. 57-66).

Gao, L., Shao, M., Peng, X., and She, D. (2015).Spatio-temporal variability and temporal stability of water contents distributed within soil profiles at a hillslope scale. Catena, 132, 29-36.

Gardner, C. M. K., Robinson, D., Blyth, K., and Copper, J. D. (2001).Soil water content. p. 1-64. KA Smith and CE Mullins (ed.) Soil and environmental analysis: Physical methods. Marcel Dekker, New York. Soil water content. p. 1-64. In KA Smith and CE Mullins (ed.) Soil and environmental analysis: Physical methods. Marcel Dekker, New York.

Grabow, G. L., Ghali, I. E., Huffman, R. L., Miller, G. L., Bowman, D., and Vasanth, A. (2013). Water application efficiency and adequacy of ET-based and soil moisture-based irrigation controllers for turfgrass irrigation. Journal of Irrigation and Drainage Engineering, 139(2), 113-123.

Irrigation Association.(2007).Definition of a Smart Controller. The Irrigation Association, Falls Church, VA Available at: http://www. irrigation. org/gov/pdf/Definition_Smart_Controller. pdf (accessed 17 February 2009).

Jia, Y. H., Shao, M. A., and Jia, X. X. (2013).Spatial pattern of soil moisture and its temporal stability within profiles on a loessial slope in northwestern China. Journal of hydrology, 495, 150-161.

Jiu-Sheng, L.I., Hong-Yan, J.I., Bei, L.I., and Yu-chun, L.I.U. (2007).Wetting patterns and nitrate distributions in layered-textural soils under drip irrigation. Agricultural Sciences in China, 6(8), 970-980.

Joshi, C., Mohanty, B. P., Jacobs, J. M., and Ines, A. V. (2011). Spatiotemporal analyses of soil moisture from point to footprint 
scale in two different hydro climatic regions. Water Resources Research, 47(1).

Jury, W. A., and Horton, R. (2004). Soil Physics, 6th Edn. Hoboken.

Karandish, F., and Šimůnek, J. (2016).A field-modeling study for assessing temporal variations of soil-water-crop interactions under water-saving irrigation strategies. Agricultural Water Management, 178, 291-303.

Levin, I., Van Rooyen, P. C., and Van Rooyen, F. C. (1979). The Effect of Discharge Rate and Intermittent Water Application by Pointsource Irrigation on the Soil Moisture Distribution Pattern 1. Soil Science Society of America Journal, 43(1), 8-16.

Liu, B., and Shao, M. A. (2014). Estimation of soil water storage using temporal stability in four land uses over 10 years on the Loess Plateau, China. Journal of hydrology, 517, 974-984

McNeal, B. L., Stanley, C. D., Graham, W. D., Gilreath, P. R., Downey, D., and Creighton, J. F. (1995). Nutrient-loss trends for vegetable and citrus fields in West-Central Florida: I. Nitrate. Journal of environmental quality, 24(1), 95-100.

Middleton, J. (2006). Determination of standard deviation. U.S. Patent Application (No.11), 115,523.

Miralles-Crespo, J., and Van Iersel, M. W. (2011). A calibrated time domain transmissometry soil moisture sensor can be used for precise automated irrigation of container-grown plants. HortScience, 46(6), 889-894.

Ooi, S. K., Cooley, N., Mareels, I., Dunn, G., Dassanayake, K., and Saleem, K. (2010). Automation of on-farm irrigation: horticultural case study. IFAC Proceedings Volumes, 43(26), 256-261. 
Or, D. (1996). Drip irrigation in heterogeneous soils: Steady-state field experiments for stochastic model evaluation. Soil Science Society of America Journal, 60(5), 1339-1349.

Penna, D., Brocca, L., Borga, M., and Dalla Fontana, G. (2013).Soil moisture temporal stability at different depths on two alpine hillslopes during wet and dry periods. Journal of hydrology, 477, 55-71.

Ragheb, H. M. A. (1997).Irrigation and fertilization management for yield maximization of drip-irrigated potato grown on sandy calcareous soil. In Proceeding of the First Scientific Conference of Agric. Sci., Fac. Agric. Assiut Univ. December13-14 (Vol. 1).

Ren, D., Xu, X., Hao, Y., and Huang, G. (2016). Modeling and assessing field irrigation water use in a canal system of Hetao, upper Yellow River basin: Application to maize, sunflower and watermelon. Journal of hydrology, 532, 122-139.

Siyal, A. A., and Skaggs, T. H. (2009). Measured and simulated soil wetting patterns under porous clay pipe sub-surface irrigation. Agricultural water management, 96(6), 893-904.

Soulis, K. X., Elmaloglou, S., and Dercas, N. (2015). Investigating the effects of soil moisture sensors positioning and accuracy on soil moisture based drip irrigation scheduling systems. Agricultural Water Management, 148, 258-268.

USDA.(1997).United States Department of Agriculture. National Engineering Handbook Part 652, Irrigation Guide.

Wang, Y.N., Fan, J., Li, S.Q., Zeng, C., Wang, Q.J., 2012. Effects of sensor's laying depth for precision irrigation on growth characteristics of maturate grapes. Chin. J.Appl. Ecol. 23 (8), 20622068. 


\section{الملخص العربيى}

\section{تحديد الموضع الأمثل لأجهزة استشعار الرطوبة لنظم الرى الموضعي}

\section{معتز كمال النمر*'، أحمد محمد الثيخةّ و السبد أحمد محمد الصادق"}

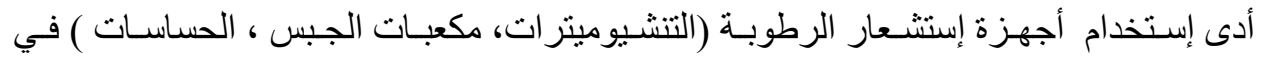
المجـال الزر اعـي بهدف إدارة الميـاه وصـيانتها إلى زيـادة الإهتمـام بتطوير إسـتر اتيجيات إدارة الري، قد يؤثر تحديد موضع أجهزة الرطوبة على أدائها في ظل ظروف تشغيلية مختلفة وبالتالي

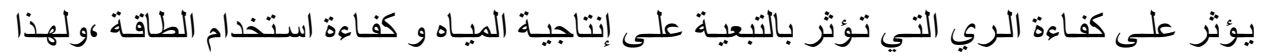

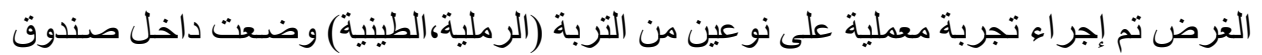

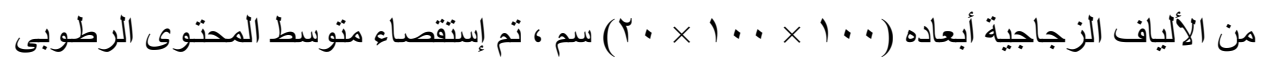

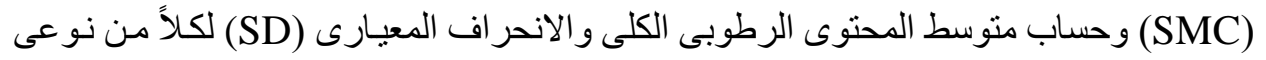

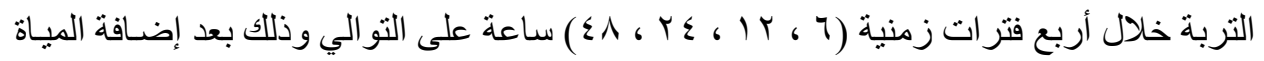

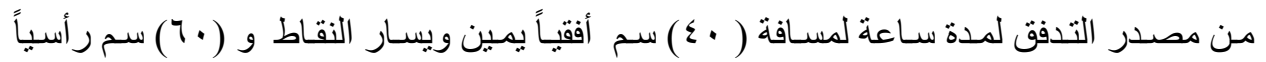

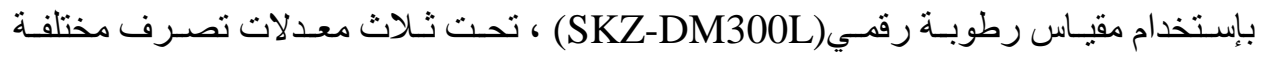

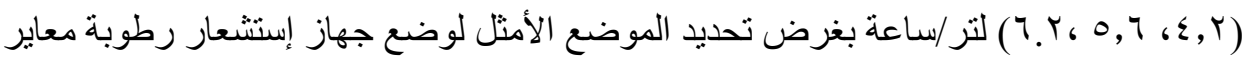

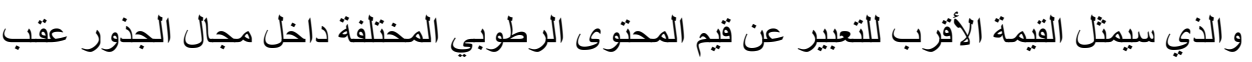

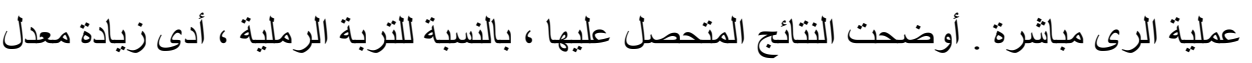

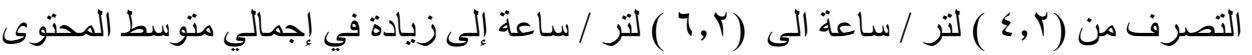

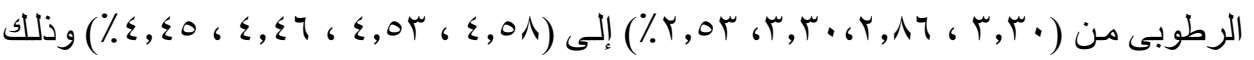

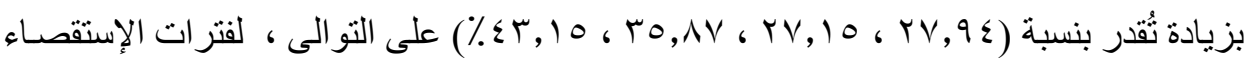

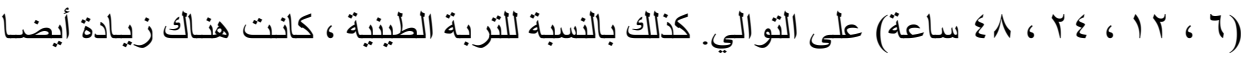

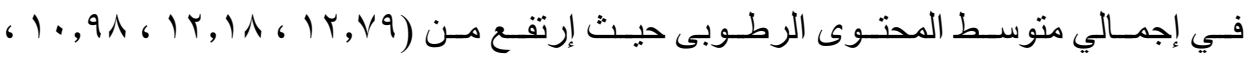

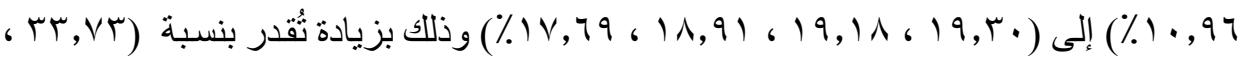

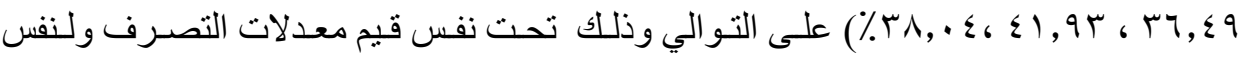

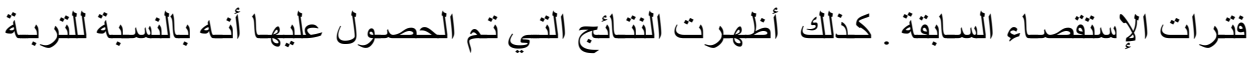

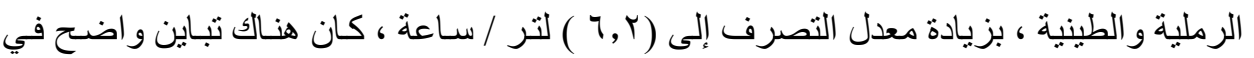

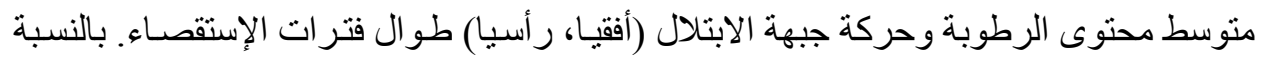

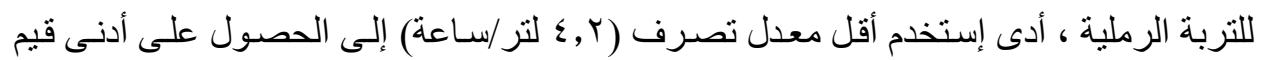

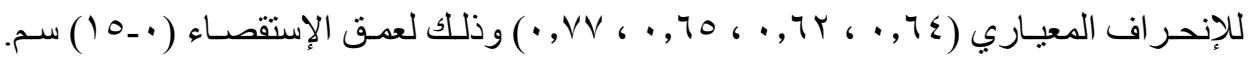
تُشير هذه القيم إلى تقارب في قيم المحتوى الرطوبى لهذا العمق على طو ال فترات الإستقصاء (

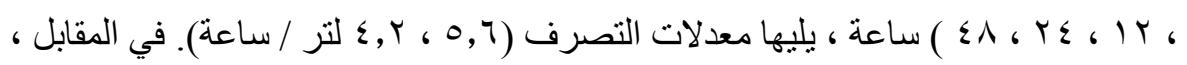




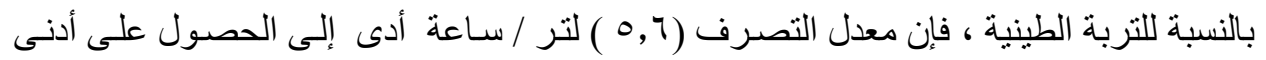

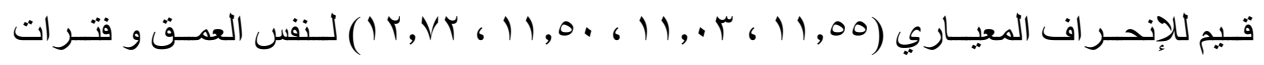

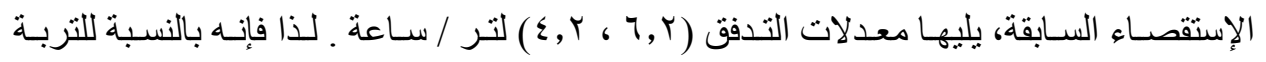

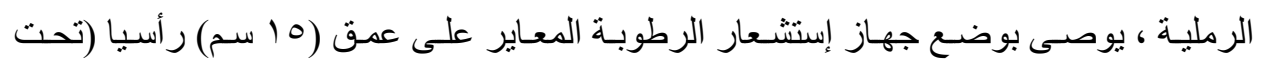

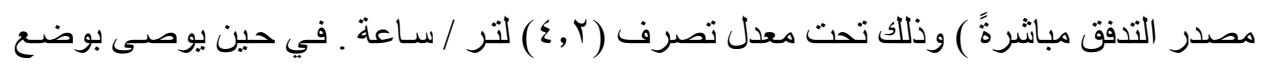

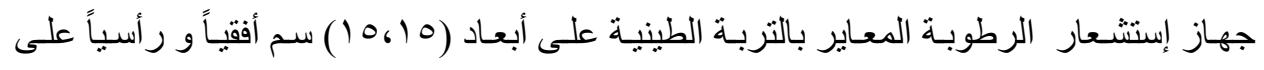

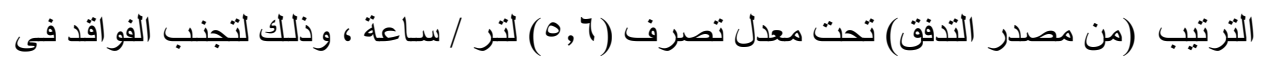
مياه الرى و الحصول على أعلى إنتاجية من المياه وكذلك أعلى كفاءة لإستخدام الطاقة. 